УДК 577.15-008.931-074

DOI

\title{
ИЗМЕНЕНИЕ АКТИВНОСТИ ЭНТЕРАЛЬНЫХ ФЕРМЕНТОВ ПОД ВЛИЯНИЕМ ФОСФОРОРГАНИЧЕСКИХ СОЕДИНЕНИЙ
}

\author{
๑В. П. Аскарьянц, Б. Б. Нигманов \\ Ташкентский педиатрический медицинский институт
}

\begin{abstract}
РЕЗЮМЕ. Целью работы было изучение изменений в ферментообразовательной функции тонкой кишки при поступлении бутифоса в небольших и сравнительно больших дозах. В результате исследования выяснилось, что наиболее типичной и постоянной при воздействии бутифоса является депрессия активности кишечнй моноглицеридлипазы, для фосфатов это характерно ингибирующее влияние на эстеразы. Активность других исследуемых кишечных ферментов при длительном использовании бутифоса изменялась волнообразно.

КЛЮчЕВЫЕ СЛОВА: моноглицеридлипаза, глицил-валин-дипептидаза, щелочная фосфатаза, амилаза, инвертаза.
\end{abstract}

Введение. Пищевые вещества в желудке подвергаются небольшой химической переработке. Их гидролиз осуществляется в основном в тонкой кишке, где происходит всасывание образующихся продуктов. Расщепление высокомолекулярных соединений на более мелкие осколки в полости тонкой кишки обеспечивают панкреатические ферменты. Заключительные стадии гидролиза осуществляются кишечными ферментами на поверхности мембран энтероцитов [5] и частично внутриклеточно. В настоящее время насчитывается более двух десятков энтеральных ферментов [8], но наиболее часто для характеристики физиологического состояния тонкой кишки В тех или иных условиях изучают энтерокиназу, пептидазы, моноглицеридлипазу, щелочную фосфатазу, дисахаридазы и амилазу - ферменты, участвующие в расщеплении основных ингредиентов пищи - белков, жиров и углеводов.

Слизистая оболочка кишечника является метаболически очень активным образованием [9]. Полное ее обновление у различных животных происходит за 36-144 часа [9]. Поэтому ядохимикаты, в механизме действия которых на организм теплокровных основнымявляется вмешательство в обменные процессы $[6,7]$, должны оказывать заметное влияние на функции тонкой кишки.

В ряде работ изучалось влияние фосфорорганических соединений на гидролитическую функцию тонкой кишки. Так, хлорофос, вводимый в желудок собак ежедневно в дозе 23 мг/кг ( $1 / 15$ Л $\left._{50}\right)$ в течение 45 дней, в начале эксперимента угнетает активность ферментов в кишечном соке. Раньше других и более выраженно снижается активность липазы. В дальнейшем активность ферментов возрастает, но в разной степени: величина активности энтерокиназы не достигает исходной, а липазы - превышает ее $[3,4]$. При введении крысам в течение трех месяцев несколько большей дозы хлорофоса $\left(1 / 10\right.$ лД $\left.{ }_{50}\right)$ отмечалось снижение дипептидазной активности и повышение инвертазной активности тонкой кишки $[1,2]$.

Целью исследования стало изучение изменений ферментообразовательной функции тонкой кишки при введении бутифоса в малых дозах и при сравнительно больших дозах.

Материал и методы исследования. В экспериментах, проведенных на крысах, в качестве функционального состояния тонкой кишки исследовалась масса соскоба всей слизистой оболочки тонкой кишки и активность основных ферментов в ее гомогенате: моноглицеридлипаза - по методу А. М. Уголева, М. Ю. Черняховской, глицил-валин-дипептидаза по методу А. М. Уголева, Н. М. Тимофеевой, щелочная фосфатаза по Bodanzky, амилаза - по методу А. М. Уголева, инвертаза - по А. М. Уголеву и Н. Н. Иезуитовой. Для опытов использовали очищенный препарат ГХЦГ, содержащий 96 \% гамма-изомера. Активность ферментов (моноглицеридлипазы, глицилвалин-дипептидазы, щелочной фосфатазы, амилазы, инвертазы) рассчитывали на 1 г сырой массы соскоба («удельная активность») и массу всей слизистой («суммарная" активность).

Результаты и их обсуждение. Нами было проведено подробное изучение воздействия на активность энтеральных ферментов широко используемого в сельском хозяйстве фосфорорганического пестицида - бутифоса.

Однократное введение бутифоса в дозе $1 / 3$ ЛД соскоба слизистой оболочки тонкой кишки крыс, получавших препарат, составляла $(2,05 \pm 0,04)$ г, у контрольных животных $-(2,13 \pm 0,02)$ г.

Очень резко изменялась активность моноглицеридлипазы. У крыс, забитых через 24 часа после введения бутифоса в дозе $1 / 3$ ЛД $_{50}$ активность этого фермента была в 8,9 раза меньше, 
Огляди літератури, оригінальні дослідження, погляд на проблему

чем у контрольных животных. Суммарная моноглицеридлипазная активность слизистой оболочки всей кишки уменьшалась в 9,2 раза.

Активность и общий запас в слизистой кишки подопытных крыс других исследуемых ферментов заметных изменений не претерпевали.

При длительном введении бутифоса крысам в дозе $1 / 20$ ЛД оболочки тонкой кишки не наблюдалось. К концу первого месяца опыта она несколько увеличивалась, на шестом месяце уменьшалась на 18,6 \%, к десятому - вновь незначительно возрастала.

Наиболее существенные сдвиги при введении бутифоса в дозе $1 / 20$ ЛД по результатам предыдущей серии опытов, были выявлены в отношении моноглицеридлипазы. Так, через 15 дней от начала введения препарата активность этого фермента снизилась в 3 раза. Примерно в такой же степени уменьшался общий запас фермента во всей слизистой кишки, так как незначительное изменение массы слизистой почти не сказалось на этом показателе. Через 1 месяц уровень липолитической активности у подопытных животных был в 3,7 раза ниже, чем у контрольных. К 2-х месячному сроку произошло максимальное (в 4,5 раза) снижение липолитической активности. К 4-му, 6-му и 10-му месяцам опыта удельная активность и общий запас в слизистой моноглицеридлипазы у подопытных групп животных были снижены в среднем на 50-70\%.

Глицил-валин-дипептидазная активность изменялась преимущественно в сторону снижения. Через 1 месяц от начала введения препарата дипептидазная активность снизилась на 17 \%. О6щий запас этого энзима вследствие некоторого увеличения массы слизистой кишечника подопытных животных не изменился. Ко 2-му и 4-му месяцам показатели дипептидазной активности подопытных животных не отличались от таковых у контрольных. К концу опытов (6-й и 10-й месяцы) уменьшение удельной и суммарной активности стало выраженным (в среднем на 45 \%).

Через 1 месяц от начала опытов активность инвертазы была снижена на 19 \%, общий ее запас в слизистой кишечника подопытных животных из-за некоторого увеличения к этому сроку массы слизистой не изменился. Через 2, 4 и 6 месяцев затравки показатели инвертазной активности у подопытных и контрольных животных не разнились. К 10-му месяцу введения бутифоса удельная и суммарная активности инвертазы снизились примерно на $40 \%$.

Активность щелочной фосфатазы в начале исследований (15 и 30 дней) имела тенденцию к повышению. Причем, суммарный запас данного фермента к концу 1-го месяца увеличился более чем на половину вследствие некоторого возрастания удельной активности и массы слизистой оболочки кишки. Повышение показателей активности щелочной фосфатазы соответственно на $43 \%$ и $30 \%$ было отмечено и на 4-м месяце затравки. В остальные сроки названные показатели у подопытных животных имели тенденцию к снижению.

Амилолитическая активность несколько повышалась через 15 дней от начала введения бутифоса в дозе $1 / 20$ ЛД ${ }_{50}$. К месячному сроку удельная и суммарная активность амилазы снижалась в среднем на 45 \%. Через 2 и 4 месяца показатели активности этого фермента у контрольных и подопытных животных почти не отличались. К 6-му месяцу эксперимента отмечалось повторное снижение показателей амилолитической активности примерно на 20 \%. К 10-му месяцу введения бутифоса, как и в начале опытов, амилолитическая активность слизистой кишечника подопытных и контрольных животных была одинаковой.

Через месяц после прекращения введения бутифоса в дозе $1 / 20$ ЛД опыта достоверных изменений массы энтероцитов не отмечалось, хотя наблюдалась тенденция к ее снижению. В конце 4-го и 6-го месяцев исследования масса соскоба слизистой оболочки подопытных и контрольных крыс становилась одинаковой. Наиболее отчетливое влияние этой дозы бутифоса сказывалось на активности моноглицеридлипазы.

Через 15 дней от начала введения пестицида активность фермента снижалась в 2,6 раза, а к концу первого месяца - в 3,3 раза. Затем разница между активностью моноглицеридлипазы в гомогенате слизистой оболочки тонкой кишки подопытных и контрольных крыс становилась меньше, но до конца исследований она все-таки оставалась достоверной. Общий запас этого фермента в слизистой кишечника во все сроки исследования уменьшался примерно в такой же степени, как и его удельная активность.

Глицил-валин-дипептидазная активность претерпевала волнообразные изменения, достоверные лишь в сторону снижения. Так, к концу первого месяца опыта бутифос вызывал снижение удельной и суммарной активностей в среднем на 15 \%, ко 2-му и 4-му месяцам названные показатели восстанавливались, а к 6-му и 10-му - вновь снижались (примерно на $25 \%$ ).

Заметные изменения в показателях инвертазной активности появились лишь в поздние сроки опытов. Индуцирующее влияние бутифоса проявилось через 4 месяца, когда инвертазная активность возрасла на 49 \%. Общий запас в слизистой данного энзима из-за снижения 
Огляди літератури, оригінальні дослідження, погляд на проблему

массы слизистой оболочки не изменился. К 6-му месяцу опытов показатели инвертазной активности превышали контрольный уровень на $46 \%$ и 34 \%, а к 10-му резко снизились и стали ниже таковых у контрольных животных на 20 \% и $19 \%$ соответственно.

При затравке крыс бутифосом в течение 1-го и 2-х месяцев наметилась тенденция к повышению активности щелочной фосфатазы относительно контроля. К концу 4-го месяца ее активность превысила контрольный уровень на 54 \%. В дальнейшем активность фермента снижалась, и к 6-му и 10-му месяцам стала такой же, как у интактных крыс.

Амилолитическая активность гомогената слизистой оболочки тонкой кишки, состоящей из активности собственно кишечной гамма-амилазы и сорбированной на поверхности энтероцитов панкреатической альфа-амилазы, на 15-й день опыта имела тенденцию к снижению. К месячному сроку эксперимента активность амилазы возрасла на $25 \%$. Поскольку в этот период масса слизистой оболочки кишечника подопытных и контрольных животных была одинаковой, воз-

\section{ЛИТЕРАТУРА}

1. Аизова О. Н. Патоморфологические изменения в желудке при хроническом отравлении гексахлораном в эксперименте / О. Н. Аизова, И. Н. Норбаев, Т. Д. Энекабқлов : Сб. тез. докл. 57-й научной конференции (секция анатомов, гистологов, эмбриологов). Самарканд, 1970. - С. 56-58.

2. Каценович Л. А. К вопросу о комбинированном действии некоторых пестицидов на состояние здоровья работающих / Л. А. Каценович, Н. Ф. Нуритдинова, К. А. Исмаилова. - В сб. : Материалы научнопрактической конференции по проблемам гигиены в условиях Узбекистана. - Ташкент, 1989. - С. 218-225.

3. Маковская Е. Н. Патологическая анатомия отравления ядохимикатами / Е. Н. Маковская. - М., 1979. - С. 82-107.

4. Платонова В.И. Функциональное состояние желудка у лиц, подвергающихся воздействию некоторых хлорорганических ядохимикатов : автореф. дисс. на со- растание общего запаса амилазы было примерно таким же, как и сдвиг ее активности, отнесенной к единице массы слизистой оболочки (27\%). Ко 2-му и 4-му месяцам опыта различий между показателями амилолитической активности у контрольных и подопытных животных не стало. На 6-м месяце эксперимента активность амилазы вновь возрасла на $11 \%$, а к концу 10-го снизилась до контрольного уровня.

Через месяц после прекращения введения пестицида активность всех ферментов и масса слизистой оболочки тонкой кишки у подопытных животных практически не отличались от таковых у контрольных.

Выводы. На основании приведенных данных можно заключить, что наиболее характерным и постоянным при воздействии бутифоса является угнетение активности кишечной моноглицеридлипазы, так как для ФОС характерно ингибирующее влияние на эстеразы, к которым относится и изучавшаяся нами моноглицеридлипаза. Активность остальных исследуемых кишечных ферментов при длительном введении бутифоса меняется волнообразно. искание научной степени канд. мед. наук / В. И. Платонова. - Киев, 1989.

5. Фудель-Осипова С. И. О некоторых подходах к изучению действия токсических веществ на организм / С. И. Фудель-Осипова. - В сб.: Гигиена и токсикология пестицидов и клиника отравлений. - Киев, 1989. - С. 178-189.

6.Шлыгин Г. К. Ферменты кишечника в норме и патологии / Г. К. Шлыгин. - М., 1967.

7. Уголев А.М. Физиология и патология пристеночного (контактного) пищеварения / А. М. Уголев. - Л., 1967.

8. David A. Regulation on small intestinal protein metabolism / A. David, L. Joseph // Gastroenterology. 2003. - Vol. 64, № 3. - P. 446-471.

9. Leblond $C$. The contact renewal of the intestinal epithelium in the albino rat / C. Leblond, C. Stevens // Anat. Res. - 2003. - Vol. 100, № 3.

\section{CHANGE THE ACTIVITY OF ENTERAL FERMENTS UNDER THE INFLUENCE PHOSHORORGANIC COMPOUNDS}

\section{Tashkent Pediatric Medical University}

SUMMARY. The aim of work was to study the changes in ferments formation function of small intestine at entering butifos in small, and comparably big doses. At the result of researchers it was revealed, that the most typical and constant at butifos influence is depression of intestinal monoglyceridlipase activity as for PhOS it is typical inhibating influence on esterase to that our studying monoglyceridlipase belongs. The activity of other examining intestinal ferments at long use butifos in changed like wave.

KEY WORDS: monoglyceridlipasa, glycil-valin-dipeptidase, alkalin phosphatase, amylase, invertase.

Отримано 2.02.2016 